\section{Lords condemn UK space policy}

\section{London}

THE British government is severely castigated this week for its persistent failure to formulate and announce a positive space policy. The criticisms, contained in a report from the influential House of Lords Select Committee on Science and Technology, will be seen as a vindication of the constantly aired grievances of the wider space community. The report (United Kingdom Space Policy, HMSO, London, £7.00) has been compiled from detailed evidence of more than 80 witnesses representing the full range of Britain's interest in space.

On funding, now at $£ 116$ million, with 70 per cent going to the European Space Agency (ESA), the report pulls no punches: "The present level of total national spending on space is wrong. It gets the worst of all worlds." It concludes that the optimum level of funding "in present circumstances" should be around $£ 200$ million after five years. The proportion of the budget devoted to domestic programmes is too little and must be adjusted "to get better value for money". The target should be for national and ESA spending to be equal.

The report takes the government to task for its delay in responding to a space plan it requested from the British National Space Centre (BNSC). Eventually, last July, the government said that no extra funds were available. The committee says: "A year was too long between the government's receipt of the space plan and its decision of July 1987; and there seems to have been no good reason why it hesitated so long. Its silence was misleading .

Furthermore, the decision was arrived at without having apparently consulted industry, something the committee "cannot understand".

The government does gain some support. The committee concurs with the stance taken by trade minister Kenneth Clarke at ESA's November meeting of ministers that Hermes should not be funded by Britain, and that a European manned space programme independent of the United States is misguided. The committee nevertheless advocates that Britain "should keep a foothold in launcher development by supporting Ariane 5, even if man-rated, at the same level of funding as Ariane 4".

Increased private sector spending on space should be encouraged, but the government should give a lead: ". . . it is not reasonable to suggest that, in an area where commercial returns are distant, British industry should step in where the government itself has declined to act.

Simon Hadlington

\title{
Lack of telecommunication among satellite companies
}

\section{Washington}

THE US company Pan American Satellite has recently become a squeaky wheel in the international telecommunications world, and it seems that the US government may be inclined to give it some grease. PanAmSat has complained in fullpage advertisements in the Washington Post and Financial Times that it is being excluded from carrying potentially lucrative communications traffic between the United States and Great Britain. Now the US government has agreed that PanAmSat's complaint is justified, and it intends take the matter up on a government-to-government basis.

PanAmSat is seeking to become a socalled separate system, offering transmission of data, television signals and private telephone lines outside the Intelsat system. Intelsat has exclusive rights to international traffic in public telephone switching, but will offer interconnections for separate systems so long as there is no infringement of its exclusive domain.

PanAmSat's chairman, Rene Anselmo, wrote to President Reagan on 29 December last year, pointing out the irony of his company's dilemma. The United States, Anselmo wrote, has lobbied hard for Cable \& Wireless, a British company, to be given access to the Japanese telecommunications market as part of a consortium with the US company Pacific Telesis. Cable \& Wireless also has landing rights for its signals in the United States.

But it is Mercury, a Cable \& Wireless subsidiary, along with British Telecom, that PanAmSat says has effectively excluded it from the British market by refusing to negotiate an operating agreement for landing rights. For its part, a

spokesman for Cable \& Wireless says PanAmSat has asked for services relating to transmitting television signals that would violate Cable \& Wireless's licence agreement in Britain, so it cannot comply. The spokesman says there have been no negotiations since last summer.

Problems in gaining access to European telecommunications markets are not limited to the United Kingdom. Tim Shea of the Commerce Department Office of Telecommunications says other European countries have been similarly unwilling to allow separate systems to enter their markets. The US government feels that European telecommunications monopolies have been two-faced in their attitude about separate systems. They have refused to deal with companies like PanAmSat, but they have been promoting Eutelsat, a separate system justified on the basis of being a regional system, although it crosses international boundaries.

For PanAmSat there is a special urgency to break the current logjam. Its RCA Astro 3000 spacecraft is due to be launched on Ariane flight V22, now scheduled for April. An agreement with Latin American countries on use of the satellite is unlikely to be lucrative.

Other companies are also anxious to see greater openness in global telecommunications. But the US government is torn. Comsat, the US member of Intelsat and the largest shareholder in the operation, stands to lose if companies such as PanAmSat can skim the cream from heavily trafficked routes. American Telephone \& Telegraph is also a heavy user of Intelsat services. So there is significant pressure to leave things as they are.

Joseph Palca

\section{Space University prepares for lift-off}

\section{London}

AN ambitious new international venture to provide aspiring space scientists with academic tuition across the range of space-related topics is in the final stages of preparation. This summer, the first batch of 100 students from around the world will attend a nine-week multidisciplinary course at the Massachusetts Institute of Technology (MIT) under the auspices of the International Space University (ISU).

The university was launched last April at MIT, with grants of $\$ 170,000$ from the National Aeronautics and Space Administration and $\$ 50,000$ from MIT. ISU's advisory board comprises an impressive assembly of internationally recognized figures from the space community, including Reimar Lüst, director-general of the
European Space Agency, and Roald Sagdeev, director of the Soviet Union's Institute for Space Research.

Participating nations include China, Japan and several European states. Britain came into the university relatively late in the day, receiving an official invitation to join at the International Astronautic Federation conference last October. The British Foundation for the ISU is trying to raise $£ 30,000$ to send six students on the first course. The British Foundation's steering committee chairman, Roy Gibson, former head of Britain's national space programme, sees private sponsorship as an ideal opportunity for space industrialists to demonstrate to the government a willingness to fund space science at a fundamental level. Simon Hadlington 